\title{
S Design of A Hydrogen Fuel Cell Car
}

\author{
Eisa Alsakkaf \\ Department of Electrical Engineering, University of Bridgeport, Bridgeport, CT, USA
}

\begin{abstract}
The objective of this document is to design the Hydrogen Fuel cell that runs from Gasoline. At first, Hydrogen is produced from Gasoline. The calculations for the emf, current, Amount of cell, number of parallel cells, and number of series cells, Power, Power Electronics rating, weight of car, Fuel consumption has been made at STP. The LabVIEW program for the designing of Hydrogen fuel cell has been created and result of the program at STP has been discussed.
\end{abstract}

Keywords: LabVIEW, Fuel cell, emf, Power Electronics Rating.

\section{INTRODUCTION}

Hybrid Car are the types of the car that uses two types of power such as internal combustion engines in combination with the electric motor. Normally the principle of combination of operation of internal combustion engine is that it uses power that can be solely from one source and can be the combination of two sources. Modern hybrid cars use fuel cell as well. Both from the point of view of global warming and from that of the inevitable exhaustion of Earth's oil reserves, it has become highly desirable to develop an alternative energy source for automobiles. Since the development of the proton exchange membrane (PEM) fuel cell, which is fuelled by hydrogen and oxygen (air) and produces only water, hydrogen has generally been seen to be the most promising approach (see accompanying article in this issue). However, although the development of fuel cell technology appears to be progressing smoothly towards eventual commercial exploitation, a viable method for storing hydrogen on board a vehicle is still to be established. The US Department of Energy (DoE) has taken what is perhaps an extreme view of what the technology needs to deliver [1].

A Fuel cell is a device that converts chemical energy into electrical energy. This energy is used in hybrid car to power up the motor. A fuel cell operates with some gaseous or liquid material as input quantity. At the anode a catalyst oxidizes the fuel, usually hydrogen, turning hydrogen into a positively charged ion and a negatively charged electron. The electrolyte is a substance specifically designed so ions can pass through it but the electrons cannot. The freed electrons travel through a wire creating the electronic current. The ions travel from electrolyte to the cathode. Upon reaching the cathode, the ions are reunited with the electrons and the two react with a third chemical, usually oxygen, to create water or carbon dioxide. Mostly Carbon monoxide is produced but $\mathrm{CO}$ can be used in the cell to produce more water. In this way removal of toxic components can be contaminated.

The important design features in a fuel cell are:

- The substance in the electrolyte. The electrolytic substance that defines the type of fuel cell.

- The fuel that is used. The most commonly used fuel is hydrogen.
- The anode catalyst that breaks down the fuel into electrons and ions. The anode catalyst is usually made up of fine platinum powder.

- The cathode catalyst turns the ions into the waste chemicals like water or carbon dioxide. The cathode catalyst is made up of nickel but it can also be a nanomaterial-based catalyst.

Liquid hydrogen can be stored on board the vehicle, as has been demonstrated by BMW who have produced a limited series of cars fuelled in this way [3]. In this case, most of the hydrogen is supplied to a conventional internal combustion engine (ICE) with some going to a fuel cell which provides the electrical power for air conditioning etc. This approach yields a gravimetric storage density of $100 \% \mathrm{H} 2$. However, if you include the mass of the tank, this is reduced to about $10 \%$ gravimetric H2. Moreover, it has two major disadvantages: (1) there is inevitably a boiloff rate which is currently $\sim 1 \%$ /day; (2) there is an inevitable energy loss due to the refrigeration process which amounts to $30 \%$ of the energy available from burning the hydrogen, even in the largest plant size. The second approach is to store the hydrogen at high pressures. A conventional steel hydrogen cylinder achieves about $1 \%$ gravimetric hydrogen. Recent developments of fibrereinforced resin have reached pressures of 700 bar, corresponding to about half the density of liquid hydrogen. The CUTE hydrogen-fuelled buses [5], as have been operating recently in London, actually use conventional steel hydrogen cylinders (150 bars).

\section{DESIGN CALCULATION}

2. 1 Chemical Equation

The general fuel cell reaction is given below.

$\mathrm{CxHY}+\mathrm{y} . \mathrm{H} 2 \mathrm{O} \rightarrow \mathrm{x} . \mathrm{CO}+1 / 2(\mathrm{y}+\mathrm{x}) . \mathrm{H} 2$

Using the Formula of Gasoline (C8H18), the above reaction becomes:

For SR: $\mathrm{C} 8 \mathrm{H} 18+18 . \mathrm{H} 2 \mathrm{O} \rightarrow 8 \mathrm{CO}+13 . \mathrm{H} 2$

As the $\mathrm{CO}$ is toxic and has to be removed from the system, so now $\mathrm{CO}$ reaction becomes:

For WGS: $\quad 8 \mathrm{CO}+8 \mathrm{H} 2 \mathrm{O} \rightarrow 8 \mathrm{CO} 2+8 \mathrm{H} 2$ 
Adding the reaction (1) and (2), gives us the below Current:

reaction:

$\mathrm{C} 8 \mathrm{H} 18+26 . \mathrm{H} 2 \mathrm{O} \rightarrow 8 \mathrm{CO}+21 . \mathrm{H} 2$

\subsection{Steam-to-Carbon Ratio:}

The steam-to-carbon is the estimated from the reactants in reaction

$\mathrm{S} / \mathrm{C}=26$

\subsection{Hydrogen Yield:}

The Hydrogen yield can be calculated by getting the number of moles in reaction

YHydrogen $=(21) /(21+8)=0.72$

2.4. Estimation of Hydrogen from Gasoline:

As, the given quantity of gasoline is 15 Gallons, so therefore 15 Gallons = 57 liters, produces almost 42 liter of Hydrogen. This has been estimated by qualitative analysis on the reaction.

57 liter of gasoline produces $=42.2$ liter of Hydrogen 1 liter of gasoline produces $=42.2 / 57$ liter of Hydrogen

Fuel Consumption:

The general formula for the consumption of fuel in fuel cell is:

Fuel Consumption $=$ (Running Distance

$(\mathrm{Km})) /($ Quantity $(\mathrm{Kg}))$

Fuel Consumption $=483 / 42.2$

Fuel Consumption $=11.5 \mathrm{Km} / \mathrm{Kg}$

2.6. Volume of Hydrogen gas:

So, now the volume of Hydrogen gas comes out to be,

Volume of Hydrogen gas $=0.73 \mathrm{x}$ volume of gasoline

Volume of Hydrogen gas $=42.2$ liters

\subsection{Pressure of Hydrogen gas:}

The pressure of Hydrogen in the cylinder can be calculated as:

Pressure $=$ no. of moles $\mathrm{x}$ Ideal gas constant $\mathrm{x}$ (Temperature/Volume) (5)

Ideal gas constant $=\mathrm{R}=0.0821 \mathrm{Nm}-2$ mol- $1 \mathrm{dm}-3 \mathrm{~K}-1$

So. The pressure at the room temperature can be given as:

Pressure $=42.2 \times 0.0821 \times 298 / 42.2$

Pressure $=24.4 \mathrm{Nm}-2$

Pressure is related to the temperature, therefore as the temperature changes, pressure changes accordingly.

Open Circuit Voltage:

The general mathematical equation for open circuit can be given as:

$\mathrm{E}=\mathrm{E} 0-0.0008460 \times(\mathrm{T}-298)+0.000043085 * \mathrm{~T} *(\log$

(Pressure of Hydrogen) (6) + $0.5 * \log$

(PAir*0.21) - $\log (\mathrm{PH} 20))$;

$\mathrm{E}=\mathrm{E} 0-0.0008460 \times(298-298)+0.000043085 * 298 *(\log$

$(24.4)+0.5 * \log ($ PAir*0.21) $-\log (\mathrm{PH} 20))$

$\mathrm{E}=\mathrm{V}=8.60 \mathrm{~V}$

The above equation (6) is valid only when water is in liquid state, while for water in gaseous state, the term $\mathrm{PH} 20=0$. The constant E0 for the hydrogen fuel cell is:
The current can be given and calculated using ohm's law:

$$
\begin{gathered}
\mathrm{V}=\mathrm{I} \times \mathrm{R} \\
\mathrm{I}=\mathrm{V} / \mathrm{R}=1.2193 \mathrm{~A}
\end{gathered}
$$

Fuel Cell Stack Topology:

In order to increase the overall voltage, the fuel cells are added in series, while in order to increase the capacity of current passed through the Load, the number of fuel cells are connected in parallel. Whereas in modern designed system, fuel cells are connected both in series and in parallel [4].

Amount of Hydrogen consumed:

The amount of Hydrogen consumed per second can be estimated by the below relation:

$$
\begin{gathered}
\mathrm{H} 2=2 *(\mathrm{I} / \mathrm{Np}) *(\mathrm{~Np} * \mathrm{Ns}) /(2 * 96485) \\
\mathrm{H} 2=2 *(1.21 / 10) *(10 * 10) /(2 * 96485) \\
\mathrm{H} 2=0.000126 \mathrm{~g} / \mathrm{s}
\end{gathered}
$$

While the terms Ns and $\mathrm{Np}$ are the number of cells in series and number of fuel cells connected in parallel in fuel cell stack.

Maximum Power:

The maximum power can be obtained by the following given relation:

$$
\begin{gathered}
\operatorname{Pmax}=\mathrm{E} * \mathrm{I} \\
\mathrm{Pmax}=8.6 * 12 \\
\operatorname{Pmax}=105 \mathrm{~W}
\end{gathered}
$$

Where E is the voltage obtained by keeping " $n$ " no of cells in series and $I$ is the current flowing through the load and will be after "n" no of cells.

Battery Voltage:

Using the normal car batteries for Fuel cell stack based power system, the selected operated battery voltage is $24 \mathrm{~V}$.

Power Electronics Rating:

There are two power electronics device involved in the circuitry with fuel cell stack to power up the hybrid car. These are DC-to-DC converter and Inverter.

DC-to-DC Converter:

There may be two type of converters possible. As the voltage required is $24 \mathrm{~V}$, so there comes the two condition when fuel cell stack voltage is lesser than $24 \mathrm{~V}$, then in this case we need a Boost converter device but if the operating voltage is larger than $24 \mathrm{~V}$, then we need a boost converter to step-down the voltage. The output of the converter is paralleled with battery to produce the smooth running. Failure or shortage of one can back up other. Fuel cell stack can also power up the device, if it has excess power.

The power rating for the power electronics based DC-toDC converter device is as same as that of the power rating of the fuel cell stack. Adding additional power rating converter can damage the fuel cell stack by drawing more current from it.

$$
\text { Prated }=\operatorname{Pmax}=105 \mathrm{~W}
$$


Inverter:

Inverter is needed to power up the motor with $\mathrm{AC}$ signal from DC supply. The power rating of the inverter is equal to the rating of motor plus the rating of the cooling system fan.

$$
\text { Prated }=\operatorname{Pmax}=105 \mathrm{~W}
$$

Cooling System Fan:

The cooling system fan has estimated to $100 \mathrm{~W}$ but it will activate only when our engine temperature becomes greater than $1000 \mathrm{C}$.

$$
\text { Pcooling }=100 \mathrm{~W}
$$

Energy or Charge Capacity:

The Charge Capacity of the battery can be calculated as:

$$
\text { Charge Capacity }=\mathrm{I} \times \mathrm{t} \quad=22 \mathrm{Ah}
$$

Supplying the Extra Power:

The extra power that must be supplied to the system is the difference between the required and used power.

Psupplied $=$ abs $($ Pused $-\mathrm{P}$ required $)$

Psupplied $=$ abs $(360-104 \mathrm{~W})$

Psupplied $=255 \mathrm{~W}$

2.18. Weight of the car:

Weight of the car is equal to the weight of the body plus the weight of the gas. In order to calculate the weight of the car, an estimation has been used.

1 Gallon of Gasoline $=$ Weight of 6.5lbs .

1 Gallon of Gasoline $=$ Weight of $2.92 \mathrm{~kg}$.

3.75 liters of Gasoline $=$ Weight of $2.92 \mathrm{~kg}$.

So,

$$
\begin{aligned}
& 1 \text { liter of Gasoline }=2.92 / 3.75 \\
& 1 \text { liter of Gasoline }=0.7735 \mathrm{~kg} .
\end{aligned}
$$

Therefore,

Total weight of the car $=$ Weight of body $+0.7735 \mathrm{x}$

Volume of gas

As, the weight of the car is constant, here assuming that Weight of the car is equal to $300 \mathrm{~kg}$, we will get the below results.

Total weight of the car $=$ Weight of body $+0.7735 \mathrm{x}$ Volume of gas

Total weight of the car $=300+0.7735 \times 57$

Total weight of the car $=300+44$

Total weight of the car $=344 \mathrm{~kg}$.

It must be keep in mind that weight of the body is constant.

\section{HYDROGEN STORAGE REQUIREMENTS}

The most compelling goals for hydrogen storage involve transportation (on-board) applications. There are two reasons for this: first, the transportation sector represents the largest consumer of oil, thus making it one of the largest sources of airborne pollutants such as carbon and nitrogen oxides. Secondly, the efficiency and economic demands to make hydrogen competitive with fossil-fuel technology are more challenging than for stationary storage. The current targets set by the U.S. Department of Energy (DOE) have been made with the concept that today's vehicles will be powered by tomorrow's higher efficiency fuel-cell power sources. The vehicles should have a similar range (480 $\mathrm{km}$ or 300 miles), operate at close to ambient conditions, and be quickly and safely refueled. Storing an acceptable density of hydrogen in porous materials by physisorption at room temperature and reasonable pressures is a challenging problem. Metalorganic frameworks (MOFs) are a new class of nanoporous materials that have shown early promise for meeting this goal [3]. They have extremely large specific surface areas, but the heats of adsorption to date are too low to provide significant storage at room temperature. In this work, molecular simulations are used to provide guidelines for the design of MOFs for hydrogen storage. To learn how much the heat of adsorption must be increased to meet current targets, we artificially increase the hydrogen/MOF Lennard-Jones attraction. The correlation of the amount of hydrogen adsorbed with the heat of adsorption, the surface area, and the free volume is revisited [4].

\section{LAB VIEW PROGRAM}

A LabVIEW program has been created that calculates the result. Using the conditions that are derived above at STP, a LabVIEW program result in comparison to that is

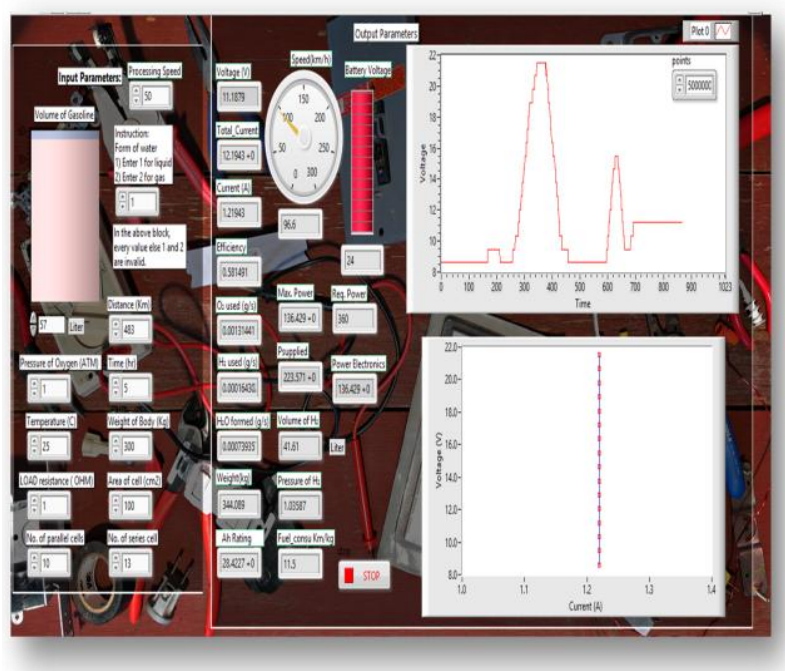

Fig.1. LabVIEW program result at STP

Voltage produced at STP vs time graph has been estimated as:

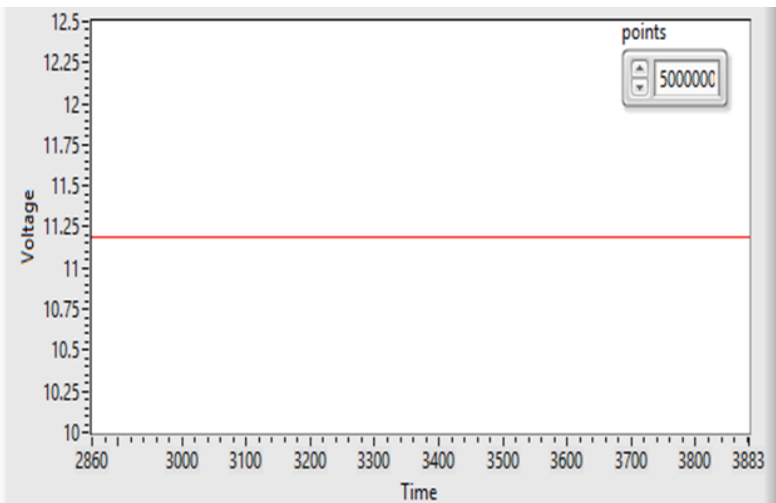

Fig.2. Voltage vs Time graph. 
INTERNATIONAL JOURNAL OF INNOVATIVE RESEARCH IN ELECTRICAL, ELECTRONICS, INSTRUMENTATION AND CONTROL ENGINEERING Vol. 4, Issue 5, May 2016

Voltage vs Current using different values of voltage.

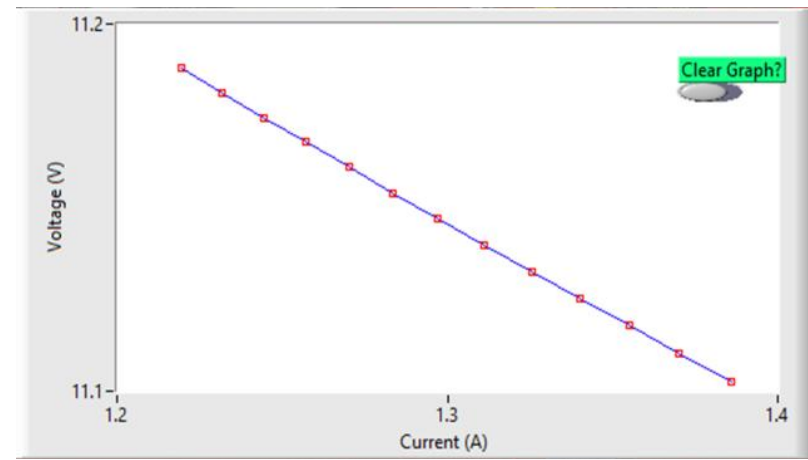

Fig.3. Voltage vs Current Graph

\section{CONCLUSIONS}

All the attached calculations are at STP and at room temp while in LabVIEW program, conditions can be applied manually and can be changed from STP. Results obtained from LabVIEW and calculations at STP are same and exactly in accordance with each other. The search for a material that is capable of storing hydrogen in the amounts necessary to make a hydrogen-fuelled fuel cell car a practical proposition has become a major objective of materials research. The DoE targets of $6 \%$ by mass, combined with adequate rates of refuelling the vehicle, will clearly be very tough to meet.

\section{REFERENCES}

[1] Ross, D. K. (2006). Hydrogen storage: The major technological barrier to the development of hydrogen fuel cell cars. Vacuum, 80(10), 1084-1089. doi:

[2] Satyapal, S., Petrovic, J., Read, C., Thomas, G., \& Ordaz, G. (2007). The US Department of Energy's National Hydrogen Storage Project: Progress towards meeting hydrogen-powered vehicle requirements. Catalysis today, 120(3), 246-256.

[3] Hynek, S., Fuller, W., \& Bentley, J. (1997). Hydrogen storage by carbon sorption. International Journal of Hydrogen Energy, 22(6), 601-610.

[4] Schüth, F., Bogdanović, B., \& Felderhoff, M. (2004). Light metal hydrides and complex hydrides for hydrogen storage. Chemical communications, (20), 2249-2258.

[5] Lee, H., Lee, J. W., Park, J., Seo, Y. T., Zeng, H., Moudrakovski, I. L., ... \& Ripmeester, J. A. (2005). Tuning clathrate hydrates for hydrogen storage. Nature, 434(7034), 743-746. 